\section{Antimicrobial activity of essential oils of Juniperus phoenicea from North Western Algeria}

\author{
G. Bachir Raho*, M. Otsmane and F. Sebaa \\ Department of Biology, University of Mascara, BP 305 Route de Mamounia Mascara, Mascara \\ 29000, Algeria
}

\begin{abstract}
Juniperus phoenicea (Family: Cupressaceae) is an evergreen tree widely distributed in North Africa including Algeria. The aim of this investigation was to analyse the antimicrobial potential of essential oils from J. phoenicea on Staphylococcus aureus, Escherichia coli, Pseudomonas aeruginosa, Klebsiella pneumonia, Streptococcus sp, Bacillus sp and Candida albicans using wells and discs diffusion methods. Broth dilution method was utilized to study the minimum inhibitory concentrations (MIC) and minimum bactericidal concentrations (MBC). The results showed a variable degree of antimicrobial activity. The diameters of inhibition zones for all test organisms were in the ranges of $7-21 \mathrm{~mm}$, while MIC was from 62.5 to $>500 \mu \mathrm{l} / \mathrm{ml}$ and MBC from 250 to $>500 \mu \mathrm{l} / \mathrm{ml}$. The highest antimicrobial activities were observed against Gram positive bacteria followed by Gram negative ones then Candida albicans. The findings provide the evidence that J. phoenicea as a good medicinal plant for further investigations.
\end{abstract}

Key words:

Juniperus phoenicea, essential oils, microorganisms, antimicrobial activity
Received:
02 May 2017

Accepted:

30 May 2017

Published:

01 June 2017

*Corresponding Author:

G. Bachir Raho

Department of Biology, University of Mascara, BP 305 Route de Mamounia Mascara, Mascara 29000, Algeria

Email:

bachir_raho

@yahoo.fr

Citation:

Bachir Raho, G.,

Otsmane, M., \& Sebaa, F. (2017). Antimicrobial activity of essential oils of Juniperus phoenicea from North Western Algeria. Journal of Medicinal Botany, 1, 01-07. doi: 10.25081/jmb.2017.v1.41

\section{Introduction}

Antibiotic resistance by microorganisms is turning into an expanding health concern and the need to find new antimicrobial agents is highly demanding. One approach includes the scan for new remedial operators with novel methods of activity from natural resources like plants and plant based products like secondary metabolites (Brantner and Grein, 1996). Medicinal and aromatice plants are generally utilized as a part of traditional antimicrobial agents and their essential oils, blends volatile compounds have been known to have antibacterial and antifungal properties. Past works have proposed that few fundamental oils indicated imperative antimicrobial actions against numerous pathogens (Pinto et al., 2003; Salgueiro et al., 2003; Pina-Vaz et al., 2004).
In Mediterranean regions, there are many native plants which belongs to the genus Juniperus, of Cupressaceae family. The flora of Algeria lists two sections and five Juniperus species; Sect. Oxycedrus (J. communis, J. oxycedru), and Sabina (J. thurifera, J. phonicea, J. sabina) (Quezel and Santa, 1963; Maire, 1967; Adams et al., 2003). J. phoenicea is a shrub or a small tree which is believed to be originated in northern lands bordering the Mediterranean Sea from Portugal to Palestine and also considered as native to North Africa and mainly found in Libya, Algeria, Morocco and Canary Islands (Alfitori et al., 2014).

In traditional medicine, this plant is considered as highly valuable medicinal plant with properties like treatment in diarrhea,

\footnotetext{
CThis article is open access and licensed under the terms of the Creative Commons Attribution License (http://creativecommons.org/licenses/by/4.0/) which permits unrestricted, use, distribution and reproduction in any medium, or format for any purpose, even commercially provided the work is properly cited. Attribution - You must give appropriate credit, provide a link to the license, and indicate if changes were made. 
rheumatism and diabetes (Bellakhder, 1997; Allali et al., 2008).

This plant has been used as steam inhalant for bronchitis and to control arthritis, berries of this plant is used as an oral hypoglycaemic agent (Amer et al., 1994), whereas the leaves are used against bronco-pulmonary disease and as a diuretic (Bellakhder, 1997).

The chemical variability of the essential oil of J. phoenicea var. turbinata is already reported from Algeria (Bekhechi et al., 2012). The aim of this paper was to assess the antimicrobial activity of the obtained essential oils against Escherichia coli, Klebsiella pneumonia, Pseudomonas aeruginosa, Staphylococcus aureus, Streptococcus sp, Bacillus sp and Candida albicans.

\section{Materials and methods \\ Plant Material}

J. phoenicea leaves were collected from the north-western part of Algeria, in the Madrousa region, province of Tiaret. They were identified by Dr. Belgherbi Benamar, Mascara University (Algeria).

\section{Extraction of essential oils}

$100 \mathrm{~g}$ of the dry leaves of $J$. phoenicea were subjected to hydro distillation for $3 \mathrm{~h}$ with 500 $\mathrm{ml}$ distilled water using a Clevenger-type apparatus. The prepared volatile oils were dehydrated over anhydrous sodium sulphate and stored in dark vials in refrigerator at $4^{\circ} \mathrm{C}$ until analyzed. Essential oil yield was $0.048 \%$ (w/w).

\section{Microbial strains}

The antimicrobial activity was individually tested against a panel of microorganisms, including Staphylococcus aureus (ATCC 25923), Escherichia coli (ATCC 25922), Pseudomonas aeruginosa (ATCC 27853), Klebsiella pneumonia (ATCC 700603), obtained from Microbiology laboratory, Tlemcen university (Algeria), Streptococcus sp and Bacillus sp (from clinical sample) supplied by Medicinal analysis laboratory, hospital of Mohammadia (province of Mascara, Algeria), and Candida albicans (ATCC 10231) provided from Microbiology laboratory, Oran university (Algeria).

\section{Determination of antimicrobial activity Agar diffusion method}

This method was carried out according to Mazari et al. (2010) with modification. Mueller-
Hinton agar was used for cultivation of bacteria, and Sabouraud for cultivation of yeast. In this method, pre-sterilized paper discs $(6 \mathrm{~mm}$ in diameter) were impregnated with $10 \mu \mathrm{l}$ of each oil dissolved in DMSO and applied on the surface of agar plates freshly seeded with standard inoculums of young cultures, 18-24 h old bacteria and yeast. The DMSO solvent was used as the negative control. Standard antibiotics Gentamycin (10 $\mu \mathrm{g} /$ disk) was used as positive controls for bacteria and Amphotericin B $(20 \mu \mathrm{g} / \mathrm{disk})$ for $C$. albicans. The plates of test organisms were then incubated at $37^{\circ} \mathrm{C}$ for $24 \mathrm{~h}$ for bacteria and $30^{\circ} \mathrm{C}$ for $24 \mathrm{~h}$ for yeast. At the end of the incubation period, the diameters of inhibition zones were measured in millimeters.

\section{Agar-well diffusion method}

The agar well-diffusion method was followed to determine the antimicrobial activity as reported by Reddy et al. (2013) with modification. Mueller Hinton and Sabouraud plates were swabbed (sterile cotton swabs) with microorganism cultures. Wells were made on the agar surface with $6 \mathrm{~mm}$ cork borer. Different dilutions of the essential oils (Pure, 1/2, 1/4, $1 / 8,1 / 16$, and $1 / 32$ ) were added with a sterile syringe into the wells. The plates were incubated at $37^{\circ} \mathrm{C}$ for the bacteria and $30^{\circ} \mathrm{C}$ for the yeast, for $24 \mathrm{~h}$. Negative and positive controls were used. The inhibition zones formed around the wells were measured in millimeters.

\section{Determination of minimum inhibitory concentration (MIC) and minimum microbiocidal concentration (MBC) of essential oil}

The minimum inhibitory concentration (MIC) and minimum bactericidal concentration (MBC) of each tested essential oil were determined using a broth dilution method (Almeida et al., 2013; Riahi et al., 2013) and as explained by Bachir et al. (2017).

\section{Results and discussions}

The crude essential oil of J. phoenicea showed antimicrobial activities against all the tested bacteria and $C$. albicans. It is shown that the susceptibility of the bacteria and C. albicans to the essential oil on the basis of inhibition zone diameters were differed based on the method used and microorganism (Figure 1 and Table 1). 
The diameters of inhibition zone values (DIZ) of essential oil of J. phoenicea showed significant variation. There was moderate antimicrobial effect in essential oil against the microorganisms. The highest activity was observed on bacteria. The DIZ for bacterial strains and $C$. albicans were in the ranges of $7-$ $21 \mathrm{~mm}$ and $8-19 \mathrm{~mm}$ respectively (Figure 1 and Table 1). This activity was highest at pure oil and was observed to decrease with concentration. This result was in accordance with previous studies which reported that bacterial strains were generally more sensitive to the essential oils than yeasts (Erkmen and Özcan, 2004; Helal et al., 2006; Obame et al., 2008).

In this study, we noted that Gram-positive bacteria ( $S$. aureus, Streptococcus. sp and Bacillus. sp) were more susceptible to $J$. phoenicea essential oil than Gram-negative bacteria (K. pneumoniea, E. coli and $P$. aeruginosa). As shown in Figure 1 and Table $1, S$. aureus was the most sensitive of the microorganisms to the $J$. phoenicea essential oil (inhibition zone $=21 \mathrm{~mm}$ ), while, $P$. aeruginosa was the most resistant strain tested against this essential oil.

Our results are in good agreement with the findings of Cantore et al. (2004) and Zarai et al. (2012). The low susceptibility of Gram-negative bacteria could be attributed to the presence of hydrophobic lipopolysaccharide in their outer membrane which provides protection against different agents (Kordali et al., 2005; Sepahvand et al., 2014; Shahi et al., 2002; Alves-Silva et al., 2013; Shahbazi, 2015).

Table 2 reports the MIC and the MBC of $J$. phoenicea oils against Escherichia coli, Staphylococcus aureus, Streptococcus sp, Bacillus sp, and Candida albicans. The oils extracted from the leaves of $J$. phoenicea exhibited weak activity against Escherichia coli (MIC $>500 \mu \mathrm{l} / \mathrm{ml}$ ), moderate activity against Bacillus sp (MIC $125 \mu \mathrm{l} / \mathrm{ml}$ and $\mathrm{MBC}>500 \mu \mathrm{l} / \mathrm{ml}$ ), and Candida albicans (MIC $125 \mu \mathrm{l} / \mathrm{ml}$ and MBC $>500 \mu \mathrm{l} / \mathrm{ml}$ ) high activity against Streptococcus sp (MIC $62.5 \mu \mathrm{l} / \mathrm{ml}$ and MBC $500 \mu \mathrm{l} / \mathrm{ml}$ ), and the strongest was shown on Staphylococcus aureus (MIC $62.5 \mu \mathrm{l} / \mathrm{ml}$ and $\mathrm{MBC}>250 \mu \mathrm{l} / \mathrm{ml}$ ).

Antimicrobial activity of the essential oils of J. phoenicea against many pathogens have been reported by many authors from many countries in the world, and really diverse results have been reported.

There is report by Angioni et al. (2003) which shows that the essential oils from the leaves of J. phoenicea ssp. turbinata exhibited weak activity against Candida albicans, Staphylococcus aureus, Escherichia coli and Pseudomonas aeruginosas.

Table 1. Diameters inhibition zones ( $\mathrm{mm}$ ) of essential oil of J. phoenicea against test organisms with disc and wells diffusion methods.

\begin{tabular}{|c|c|c|c|c|c|c|c|c|c|}
\hline \multirow{2}{*}{ Strains } & \multirow{2}{*}{ Method } & \multirow{2}{*}{ Gent } & \multicolumn{7}{|c|}{ Growth inhibition diameter (mm) } \\
\hline & & & & pure & $1 / 2$ & $1 / 4$ & $1 / 8$ & $1 / 16$ & $1 / 32$ \\
\hline \multirow[t]{2}{*}{ K. pneumoniea } & Disc & 30 & $\mathrm{NI}$ & 12 & 7 & NI & NI & NI & NI \\
\hline & Wells & 33 & $\mathrm{NI}$ & 14 & 10 & NI & NI & NI & NI \\
\hline \multirow[t]{2}{*}{ E. coli } & Disc & 20 & NI & 16 & 7 & 7 & $\mathrm{NI}$ & NI & $\mathrm{NI}$ \\
\hline & Wells & 24 & $\mathrm{NI}$ & 18 & 10 & 7 & $\mathrm{NI}$ & NI & $\mathrm{NI}$ \\
\hline \multirow[t]{2}{*}{ P. aeruginosa } & Disc & 17 & NI & 8 & 7 & $\mathrm{NI}$ & $\mathrm{NI}$ & NI & $\mathrm{NI}$ \\
\hline & Wells & 26 & NI & 10 & 7 & NI & NI & NI & $\mathrm{NI}$ \\
\hline \multirow[t]{2}{*}{ S. aureus } & Disc & 27 & NI & 19 & 12 & 10 & 8 & 7 & $\mathrm{NI}$ \\
\hline & Wells & 25 & NI & 21 & 19 & 11 & 11 & NI & $\mathrm{NI}$ \\
\hline \multirow[t]{2}{*}{ Streptococcus sp } & Disc & 23 & NI & 17 & 13 & 11 & 9 & 7 & NI \\
\hline & Wells & 23 & $\mathrm{NI}$ & 20 & 15 & 14 & 13 & 11 & $\mathrm{NI}$ \\
\hline \multirow[t]{2}{*}{ Bacillus sp } & Disc & 28 & NI & 17 & 12 & 9 & 7 & 7 & $\mathrm{NI}$ \\
\hline & Wells & 25 & NI & 16 & 14 & 10 & 7 & 7 & $\mathrm{NI}$ \\
\hline \multirow[t]{2}{*}{ C. albicans } & Disc & 25 & NI & 17 & $\mathrm{NI}$ & $\mathrm{NI}$ & NI & NI & NI \\
\hline & Wells & NI & NI & 19 & 10 & 8 & NI & NI & $\mathrm{NI}$ \\
\hline
\end{tabular}

NI: no inhibition; Gent: Gentamycin 

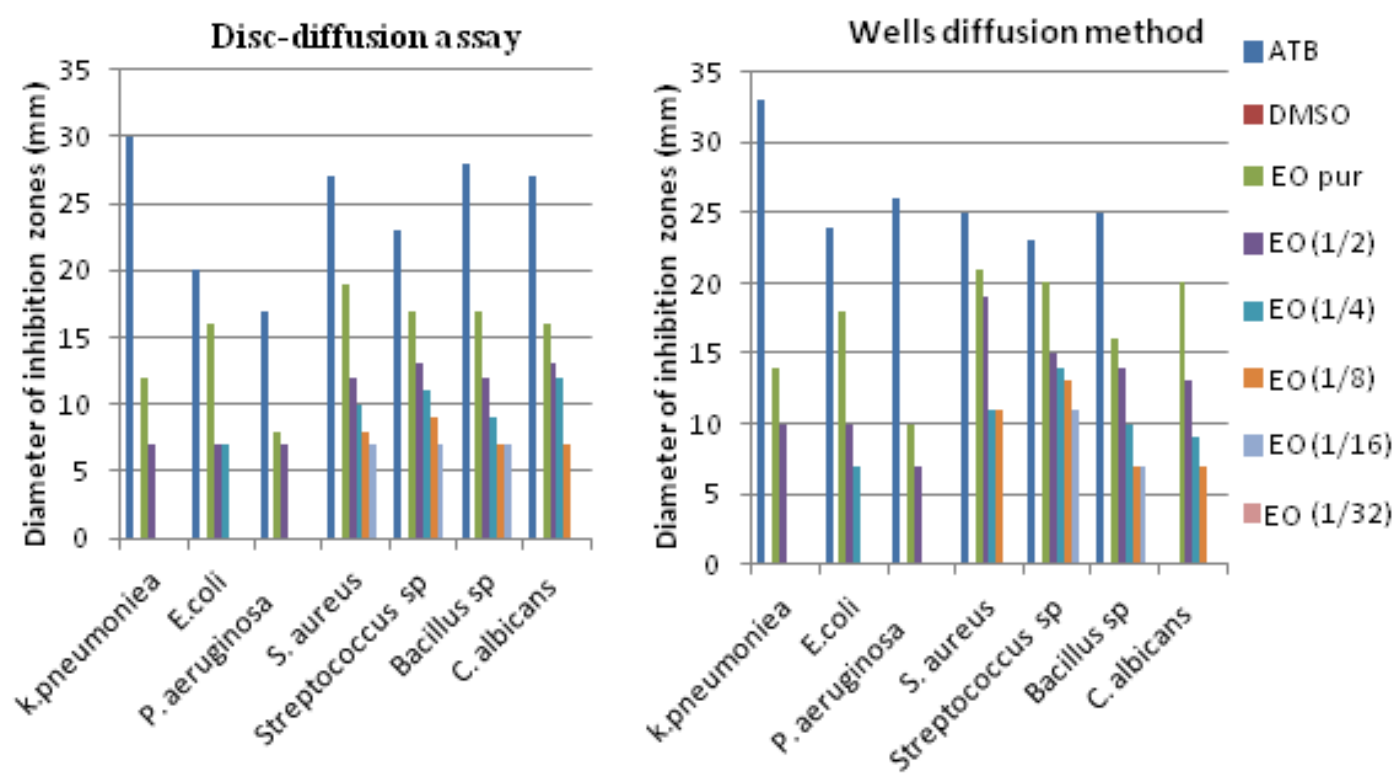

Fig. 1. Effect of essential oil of J. phoenicea on some microorganisms using wells and discs diffusion techniques.

Table 2. MBC and MIC ( $\mu \mathrm{l} / \mathrm{mL})$ of the essential oils of $J$. phoenicea against Escherichia coli, Staphylococcus aureus, Streptococcus sp, Bacillus sp and Candida albicans.

\begin{tabular}{lll}
\hline Strains & MIC & MBC \\
\hline E.coli ATCC25922 & $>500 \mu \mathrm{l} / \mathrm{ml}$ & - \\
S.aureus ATCC25923 & $62.5 \mu \mathrm{l} / \mathrm{ml}$ & $250 \mu \mathrm{l} / \mathrm{ml}$ \\
Streptococcus sp & $62.5 \mu \mathrm{l} / \mathrm{ml}$ & $500 \mu \mathrm{l} / \mathrm{ml}$ \\
Bacillus sp & $125 \mu \mathrm{l} / \mathrm{ml}$ & $500 \mu \mathrm{l} / \mathrm{ml}$ \\
C.albicans ATCC 10231 & $125 \mu \mathrm{l} / \mathrm{ml}$ & $>500 \mu \mathrm{l} / \mathrm{ml}$ \\
\hline
\end{tabular}

Bouzouita et al. (2008) found that J. phoenicea oil shows inhibition effect against Klebsiella oxytoca, Lactobacillus plantarum, Saccharomyces cereviseae and Geotrichum candidum. Derwich et al. (2010) used essential oils of J. phoenicea to evaluate their activity on Escherichia coli, Staphylococcus aureus, Staph. intermedius, Klebsiella pneumonia, Pseudomonas aeruginosa, Bacillus subtilis and Streptococcus mutans. E. coli was the most sensitive strain with the strongest inhibition zone (34 mm), followed by $S$. aureus, $S$. intermedius and K. pneumonia, 24, 18 and $14 \mathrm{~mm}$, respectively. Modest activities were observed against $P$. aeruginosa, $B$. subtilis and $S$. mutans with inhibition zones of 10,10 and $8 \mathrm{~mm}$. The minimum inhibitory concentrations (MIC) ranging from 0.02 to $0.40 \mathrm{mg}$ per $\mathrm{mL}$. Mazari et al. (2010) examined the antimicrobial effect of $J$. phoenicea essential oil by MIC and disk diffusion methods on five bacteria (3 Gram-positive and $2 \mathrm{Gram}$ negative), and 3 fungi and reported that the essential oil had high antibacterial activity against Enterococcus feacalis with inhibition zone of 15.6 $\mathrm{mm}$ and MIC value of $7 \mu \mathrm{l} / \mathrm{ml}$, and moderately reduced the growth of Aspergillus flavus and Fusarium oxysporum.

Ait-Ouazzou et al. (2012) tested the essential oils of $J$. phoenicea on four Gram-positive, namely Staphylococcus aureus, Enterococcus faecium, Listeria monocytogenes $4 \mathrm{~b}$ and $L$. monocytogenes EGD-e, and three Gram negative bacteria: Salmonella Enteritidis, Escherichia coli $\mathrm{O} 157: \mathrm{H7}$, and Pseudomonas aeruginosa. The essential oil of J. phoenicea showed both, bacteriostatic and bactericidal activity only against the four Gram-positive strains, with diameter zone inhibition ranging from $13.1 \mathrm{~mm}$ (E. faecium) to $15.8 \mathrm{~mm}$ ( $S$. aureus), and MIC values ranging from $0.5 \mu \mathrm{L} / \mathrm{mL}$ (S. aureus) to $15 \mu \mathrm{L} / \mathrm{mL}$ (L. monocytogenes $\mathrm{EGD}-\mathrm{e})$ and $\mathrm{MBC}$ values of 10 $\mu \mathrm{L} / \mathrm{mL}$ ( $S$. aureus and $L$. monocytogenes $4 \mathrm{~b}), 15$ $\mu \mathrm{L} / \mathrm{mL}$ (L. monocytogenes EGD-e), and $30 \mu \mathrm{L} / \mathrm{mL}$ (E. faecium). In other study, Ramdani et al. (2013) tested essential oils of $J$. phoenicea of five localities from eastern Algeria against both Gram positive (Enterobacter cloacae ATCC 13047, MRSA (Methicillin-resistant Staphylococcus aureus), Staphylococcus aureus ATCC 25923) and six Gram negative bacteria (Escherichia coli ATCC 25922, Pseudomonas syringae, Salmonella sp, Serratia liquefaciens 
ATCC 27592, Serratia marcescens ATCC 14756, Shigella sp), and found that oil of the population of Elhadjaz shows a significant activity on all the bacteria tested. Elsewhere, Elmhdwi et al. (2015) reported that $J$. phoenicea extracts $(70 \%$ methanol, $70 \%$ ethanol and 70\% acetone) at concentration of $20 \%, 30 \%$ and $40 \%$ were effective against both Gram-positive (Staphylococcus aureus) and Gramnegative bacteria (Escherichia coli, Pseudomonas aeruginosa, Klebsiella pneumonia and Acinetobacter sp.).

The antimicrobial activity of essential oils depends on their chemical composition (Teixeira et al., 2012). Their biological activities are often attributed to their major components (AitOuazzou et al., 2012). In previous reports, the antimicrobial activity of essential oils of Juniperus phoenicea can be attributed to the presence of high concentration of $\alpha$-pinene (Mazari et al., 2010; Ramdani et al., 2013; Elmhdwi et al., 2012) on the chemical composition of J. phoenicea oil from Algeria. $\alpha$-pinene has been found to have relatively strong antimicrobial properties against many important pathogens and spoilage organisms (Bourkhiss et al., 2007; Safaei-Ghomi and Ahd, 2010).

It crushes the cellular integrity of Gram positive microbes and inhibit respiratory action in yeast mitochondria and had some antifungal movement however Gram negative bacteria were more resistant to it (Andrews et al., 1980). In addition, other compounds such as $\beta$ Phellandrene, D-germacrene and $\alpha$-terpinyl acetate which have antimicrobial properties may be responsible for this activity (Hernández et al., 2008; Ngassapa et al., 2003; Simic et al., 2002). However, the parts with lower concentrations, may likewise be adding to the antimicrobial activity of the oil. In this manner, the synergistic impacts of the different major and minor parts of the basic oils ought to be contemplated to represent the oil organic action (Burt, 2004).

\section{Conclusion}

The essential oils of $J$. phoenicea leaves hindered the development of both bacteria and C. albicans and shows both a bacteriostatic and bactericidal impacts on tried microorganisms. Our outcomes legitimize the utilization of this plant by conventional healers in the treatment of specific sicknesses and recommend that $J$. phoenicea oils could be filled in as a vital characteristic option for antimicrobial drug development research.

\section{Author contributions}

All authors contributed equally in the study and preparation of article. All authors approved the final version of the manuscript for publication.

\section{References}

Adams, R.P., Mumba, L.E., James, S.A., Pandey, R.N., Gauquelin, T., \& Badri, W. (2003). Geographic variation in the leaf oils and DNA Fingerprints (RAPDs) of Juniperus thurifera L. from Morocco and Europe. Journal of Essential Oil Research, 15, 148-154.

Ait-Ouazzou, A., Lorán, S., Arakrak, A., Laglaoui, A., Rota, C., Herrera, A., Pagán, R., \& Conchello, P. (2012). Evaluation of the chemical composition and antimicrobial activity of Mentha pulegium, Juniperus phoenicea, and Cyperus longus essential oils from Morocco. Food Research International, 45, 313319.

Alfitori M.O., Lamlom S.H. \& Aly H.M. (2014). Essential Oil Composition of Leaves of Juniperus phoenicea Grown at Al-Jabel AlAkhdar Region, Libya. Middle-East Journal of Scientific Research, 22 (3), 368-370.

Allali, H., Benmehdi, H., Dib, M.A., Tabti, B., Ghalem, S., \& Benabadji, N. (2008). Phytotherapy of diabetes in West Algeria. Asian Journal of Chemistry, 20, 2701-2710.

Almeida, R. B. A., Akisue, G., Cardoso, L. M. L., Junqueira, J. C., \& Jorge, A. O. (2013). Antimicrobial activity of the essential oil of Cymbopogon citratus (DC) Stapf. on Staphylococcus spp., Streptococcus mutans and Candida spp. Revista Brasileira de Plantas Medicinais, 15(4), 474-482.

Alves-Silva, J. M., Dias dos Santos, S. M., Pintado, M. E., Pérez-álvarez, J. A., Fernández-López, J., \& Viuda-Martos, M. (2013). Chemical composition and in vitro antimicrobial, antifungal and antioxidant properties of essential oils obtained from some herbs widely used in Portugal. Food Control, 32(2), 371-378.

Amer, M.M.A., Wasif, M.M., \& Abo-Aytta, A.M. (1994). Chemical and biological evaluation of Juniperus phoenicea as a hypoglycaemic agent. Journal of Agricultural Research, 21, 1077-1091. 
Andrews, R.E., Parks, L.W., \& Spence, K.D. (1980). Some effects of douglas fir terpenes on certain microorganisms. Applied and Environmental Microbiology, 40(2), 301-304.

Angioni, A., Barra, A., Russo, MT., Coroneo, V., Dessiä, S., \& Cabra,s P. (2003). Chemical composition of the essential oils of Juniperus from ripe and unripe berries and leaves and their antimicrobial activity. Journal of Agricultural and Food Chemistry, 51, 3073-3078.

Bachir, R. G., Otsmane, M., \& Sebaa, F. (2017). Inhibitory effects of Juniperus oxycedrus essential oils against some pathogens. International Journal of Microbiology and Biotechnology, 2(1), 29-33.

Bekhechi, C., Atik Bekkara, F., Consiglio, D., Bighelli, A., \& Tomi, F. (2012). Chemical variability of the essential oil of Juniperus phoenicea var. turbinata from Algeria. Chemistry and Biodiversity, 9(12), 2742-53.

Bellakhder, J. (1997). La Pharmacopée Marocaine traditionnelle. Paris: Ibis Press, p. 272.

Bourkhiss, M., Hnach, M., Bourkhiss, B., Ouhssine, M., \& Chaouch, A. (2007). Composition chimique et propriétés antimicrobiennes de l'huile essentielle extraite des feuilles de Tetraclinis articulata (Vahl) du Maroc. Afrique Science, 03, 232-242.

Bouzouita, N., Kachouri, F., Ben Halima, M., \& Chaabouni, M. M. (2008). Composition chimique et activités antioxydante, antimicrobienne et insecticide de l'huile essentielle de juniperus phoenicea. Journal de la Société Chimique de Tunisie, 10, 119-125.

Brantner, A., and \& Grein, E. (1996). Antibacterial activity of plant extracts used externally in traditional medicine. Journal of Ethnopharmacology, 5, 119-122.

Burt, S. (2004). Essential oils: their antibacterial properties and potential applications in foods--a review. International Journal of Food Microbiology, 94(3), 223-53.

Cantore, P.L., Iacobellis, N.S., Marco, A.D., Capasso, F., \& Senatore, F. (2004). Antioxidant activity of Coriandrum sativum L. and Foeniculum vulgare Miller Var. vulgare (Miller) essential oils. Journal of Agricultural and Food Chemistry, 52, 7862-7866.

Derwich, E., Benziane, Z., \& Boukir, A. (2010). Chemical composition of leaf essential oil of Juniperus phoenicea and evaluation of its antibacterial activity. International Journal of Agriculture and Biology, 12, 199.

Elmhdwi, M.F, Attitalla, I.H., \& Ali Khan, B. (2015). Evaluation of antibacterial activity and antioxidant potential of different extracts from the leaves of Juniperus Phoenicea. Journal of Plant Pathology and Microbiology, 6, 9.

Erkmen, O., \& Özcan, M. (2004). Antimicrobial effects of essential oils on growth of bacteria, yeasts and molds. Journal of Essential OilBearing Plants, 7(3), 279-287.

Helal, G.A., Sarhan, M.M., Abu Shahla, A.N.K., \& Abou El-Khair, E.K. (2006). Antimicrobial activity of some essential oils against microorganisms deteriorating fruit juices. Mycobiology, 34(4), 219-229.

Hernández, T., Canales, M., Garcia, A.M., Duran, A., Meraz, S., Davila, P., \& Avila, J.G. (2008). Antifungal activity of the essential oils of two Verbenaceae: Lantana achyranthifolia and Lippia graveolens of Zapotitlan de las Salinas, Puebla (Mexico). Boletin Latinoamericano y Del Caribe de Plantas Medicinales y Aromaticas, 7, 203-207.

Kordali, S., Cakir, A., Mavi, A., Kilic, H., \& Yildirim, A. (2005). Screening of chemical composition and antifungal and antioxidant activities of the essential oils from three Turkish Artemisia Species. Journal of Agricultural and Food Chemistry, 53, 1408-1416.

Maire, R. (1967). La flore de l'Afrique du Nord, Encyclopédie biologique. Paris, France: Paul Lechevalier Editions.

Mazari, K., Bendimerad, N., Bekhechi, C., \& Fernandez, X. (2010). Chemical composition and antimicrobial activity of essential oils isolated from Algerian Juniperus phoenicea L. and Cupressus sempervirens L. Journal of Medicinal Plants Research, 4(10), 959-964.

Ngassapa, O., Runyoro, D.K.B., Harvala, E., \& Chinou, I.B., (2003). Composition and antimicrobial activity of essential oils of two populations of Tanzanian Lippia javanica (Burm.f.) Spreng (Verbenaceae). Flavour and Fragrance Journal, 18, 221-224.

Obame, L.C., Edou, P., Bassolé, I.H.N., Koudou, J., Agnaniet, H., Eba, F., \& Traore, A.S. (2008). Chemical composition, antioxidant and antimicrobial properties of the essential oil of Dacryodes edulis (G. Don). 
Lam HJ from Gabon. African Journal of Microbiology Research, (2), 148-152.

Pina-Vaz, C., Rodrigues, A.G., Pinto, E., Costa-deOliveira, S., Tavares, C., Salgueiro, L.R., Cavaleiro, C., Gonc alves, M.J. et al. (2004). Antifungal activity of Thymus oils and their major compounds. Journal of the European Academy of Dermatology, 18, 73-78.

Pinto, E., Palmeira, A., Salgueiro, L., Cavaleiro,

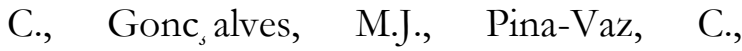
Rodrigues, A., Oliveira, S. et al. (2003). Antifungal activity of oregano oils (Lippia graveolens and Origanum virens) on dermatophyte species. Clinical Microbiology and Infection, 9(1), 222.

Quezel, F., \& Santa, S. (1963). Nouvelle flore de l'Algérie et des régions désertiques méridionales. Paris, France: CNRS Edition.

Ramdani, M., Lograda, T., Silini, H., Zeraib, A., Chalard, P., Figueredo, G., Bouchaala, M., \& Zerrar, S. (2013). Antibacterial activity of essential oils of Juniperus Phoenicea from Eastern Algeria. Journal of Applied Pharmaceutical Science, 3(11), 22-28.

Reddy, Y.S., Anitha, G., Nagulu, M., Reddy, M. R, Prasad P. H, Sweth M. J, Kumar V. R, \& Reddy G. P. CS. (2013). In vitro antibacterial activity of leaf extracts of Justicia gendarussa wild. Der Pharmacia Lettre, 5 (5), 101-103.

Riahi, L., Elferchichi, M., Ghazghazi, H., Jebali, J., Ziadi, S., Aouadhi, C., Chograni, H., Zaouali, Y., Zoghlami, N., \& Mliki, A. (2013). Phytochemistry, antioxidant and antimicrobial activities of the essential oils of Mentha rotundifolia L. in Tunisia. Industrial Crops and Products, 43, 883-889.

Safaei-Ghomi, J., \& Ahd, A.A. (2010). Antimicrobial and antifungal properties of the essential oil and methanol extracts of Eucalyptus largiflorens and Eucalyptus intertexta. Pharmacognosy Magazine, 6, 172-175.
Salgueiro, L.R., Cavaleiro, C., Pinto, E., PinaVaz, C., Rodrigues, A.G., Palmeira, A., Tavares, C., Costa-Oliveira, S. et al. (2003). Chemical composition and antifungal activity of the essential oil of Origanum virens on Candida species. Planta Medica, 69, 871-874.

Sepahvand, R., Delfan, B., Ghanbarzadeh, S., Rashidipour, M., Veiskarami, G. H., \& Ghasemian-Yadegari, J. (2014). Chemical composition, antioxidant activity and antibacterial effect of essential oil of the aerial parts of Salvia sclareoides. Asian Pacific Journal of Tropical Medicine, 7(1), S491-S496.

Shahbazi, Y. (2015). Chemical composition and in vitro antibacterial activity of Mentha spicata essential oil against common food-borne pathogenic bacteria. Journal of Pathogens, 2015, 916305.

Shahi, A. K., Pal, S., \& Dutt, P. (2002). Mentha longifolia(Linn.) Huds: a carvone rich chemotype in Jammu region. Indian Perfumer, 46(1),63-65.

Simic, N., Palic, R., Vajs, V., Milosavljevic, S., \& Djokovic, D. (2002). Composition and antibacterial activity of Acbillea asplenifolia essential oil. Journal of Essential Oil Research, 14,76-78.

Teixeira, B., Marques, A., Ramos, C., Batista, I., Serrano, C., Matos, O., \& Nunes, M. L. (2012). European pennyroyal (Mentha pulegium) from Portugal: Chemical composition of essential oil and antioxidant and antimicrobial properties of extracts and essential oil. Industrial Crops and Products, 36(1), 81-87.

Zarai, Z., Ben Chobba, I., Ben Mansour, R., Békir, A., Gharsallah, N., \& Kadri, A. (2012). Essential oil of the leaves of Ricinus communis L.: in vitro cytotoxicity and antimicrobial properties. Lipids in Health and Disease, 11, 102. 